\title{
Evaluation of Organolepictic Properties and Microbial Studies of Guava Nectar and RTS
}

\author{
Nisha Chandel ${ }^{1 *}$, Vivek Kumar Kurrey ${ }^{1}$, Pramila Seth ${ }^{1}$, \\ Apurwa Kesharwani ${ }^{1}$ and Atul Praveen Panna ${ }^{2}$ \\ ${ }^{1}$ Department of Horticulture, College of Agriculture, IGKV, Raipur (C.G.) 492012, India \\ ${ }^{2}$ Department of Fruit science, SHIATS Allahabad (UP) 211007, India \\ *Corresponding author
}

\section{A B S T R A C T}

Keywords

Guava, RTS, Nectar,

Organoleptic studies

and Microbial count.

Article Info

Accepted:

17 October 2017

Available Online:

10 December 2017
Guava products like RTS and Nectar were initially evaluated organoleptically was performed for their appearance, color, flavor, taste and overall acceptability. The score for each attributes was highest on the day of preparation which decreased with passage of time for taste, flavor and overall acceptability during storage. Organoleptic evaluation of processed products remained more acceptable for products stored at three months. However, initial microbial analysis of RTS and Nectar revealed either higher microbial count. However, the increase in microbial growth was within the permissible level. Application of heat during processing irrespective of holding time reduced the microbial load.

\section{Introduction}

Guava (Psidium guajava L.) is a member of the large Myrtaceae or Myrtle family, believed to be originated in Central America and the southern part of Mexico (Somogyi et al., 1996). It is claimed to be the fourth most important fruit in terms of area and production after mango, banana and citrus. India is the major world producer of guava (Jagtiani et al., 1998). It has been in cultivation in India since early 17 th century and gradually became a crop of commercial importance. Guava fruit is an excellent source of vitamin C containing 70 to $350 \mathrm{mg} / 100 \mathrm{~g}$, which is about two to five times more than orange and ten times to that of tomato. It is also a rich source of minerals like calcium, phosphorus, iron etc. Post-harvest management has become an absolute necessity for effective exploitation of the export potential of fruits and vegetables. Fruits and vegetables losses are estimated at $35-40 \%$ due to improper post-harvest management. With the changing consumer attitudes, demands and emergence of new market products, it has become imperative for producers to develop products, which have nutritional as well as health benefits. In this context, guava has excellent digestive and nutritive value, pleasant flavor, high palatability and availability in abundance at 
moderate price. The fresh fruit has limited shelf life therefore it is necessary to utilize the fruit for making different products to increase its availability over an extended period and to stabilize the price during the glut season.

Guava can be consumed fresh or can be processed into juice, nectar, pulp, jam, jelly, slices in syrup, fruit bar or dehydrated products, as well as being used as an additive to other fruit juices or pulps (Leite et al., 2006). These products have good potential for internal as well as external trade. The utilization of guava for preparation of beverages and intermediates moisture products has not been explored much. Guava pulp can be used as base for the preparation of these products. Nectar and RTS is one of the refreshing beverages having zero carbonation, relatively few preservatives and excellent source of several important vitamins and minerals and is used as health drink. Therefore, it is necessary to utilize guava for making nutritious processed health food like nectar to increase availability over an extended period and to stabilize the price during the glut season. To utilize the produce at the time of glut and to save it from spoilage, the processing technology for preparation guava nectar is highly required.

\section{Materials and Methods}

\section{Organoleptic evaluation of the products}

The products developed from guava were assessed every month. The qualities considered during the study were appearance, color, flavor, taste, overall acceptability and microbial studies.

\section{Development of score card}

In order to evaluate the sensory qualities of developed products, descriptive test, which analytically describes the sensory qualities of a product, was used. In order to rank the sensory qualities, ordinal scoring method (ranking) was used. Five point scale was used for ranking i.e., from 1 to 5 and details of ranks/scores are as follows. 5- Excellent; 4Good; 3- Fair; 2- Poor; 1- Very poor A score card was developed to evaluate the acceptability of the products.

\section{Microbiological evaluation of the products}

Microbiological studies were conducted at 1st and 3rd month of storage. Total plate count (TPC), yeast and mould count, coliform and E. coli were undertaken. The procedure of Cruick Shank et al., (1975) was used for total plate count and yeast and mould count.

\section{Total plate count and yeast and mould count by pour-plate method}

Ten fold serial dilution of the bacterial suspension was prepared. Normal saline was used as diluents for the organism. $9 \mathrm{ml}$ of the diluents was pipette into several sterile test tubes. The bacterial suspensions were uniformly mixed. Using a sterile $1 \mathrm{ml}$ pipette, $1 \mathrm{ml}$ of the suspension was transferred into the first tube of diluents and mixed thoroughly. From this mixed dilution, $1 \mathrm{ml}$ was transferred to the next diluents. Similar dilutions were made in the same way using fresh pipettes. $1 \mathrm{ml}$ of each dilution was pipetted into sterile petri plates and $15 \mathrm{ml}$ of molten agar medium which was cooled around $45^{\circ} \mathrm{C}$ was poured into plates containing diluted samples. The agar medium was immediately distributed by gently mixing the Petri dish in circular movements both clock wise and anti-clock wise on a flat bench and then allowed to set evenly and the inverted plates were incubated for 1-2 days and $3-5$ days at $37^{\circ} \mathrm{C}$ for bacterial and yeast and moulds respectively. For total plate count, total plate count agar and potato dextrose agar for yeast and mould count was used. 


\section{Data presentation}

All the details pertaining to organoleptic changes in the processed products like appearance, taste, color and microbial count were presented per $100 \mathrm{~g}$ of the product. Thus all the values were represented as percentage. The sensory qualities of each parameter were expressed for 5 points since the highest rank was 5. Microbiological qualities in the products were presented for $1 \mathrm{ml}$.

\section{Statistical analysis}

In order to understand the significant changes on storage, analysis of variance (ANOVA) and CRD test was carried out for sensory parameters like color, appearance, flavor, taste and overall acceptability for each product

\section{Results and Discussion}

\section{Organoleptic evaluation of stored guava products}

The products developed from guava were stored at three month storage conditions and each month they were organoleptically assessed. A maximum score of 5 was taken as standard for considering the quality of the product

\section{Organoleptic evaluation}

The effect of artificial and natural sweeteners on organoleptic qualities of guava nectar during storage is presented in the Table 1 and 2.

\section{Colour and appearances}

The maximum organoleptic score for colour and appearance of guava nectar and rts was recorded in treatment $\mathrm{T}_{3}(50 \%$ Equal $+50 \%$ Sugar) is statistically at par with $\mathrm{T}_{7}(50 \%$
Stevia $+50 \%$ Sugar) during storage. The organoleptic score for colour and appearance showed decreasing trend during storage which might be due to the action of acidity which enhances the hydrolytic reaction causes browning and acid also enhances the millard reaction and caramelization which causes more browning in product. Polyphenolic compound present in fruit pulp also reacts with enzymes to get discoloration. These findings were accordance with Kalra and Tandon (1991) in guava nectar.

\section{Aroma}

The maximum score for taste of guava nectar and rts was recorded in treatment T3 (50\% Equal $+50 \%$ Sugar) which is statistically at par with $\mathrm{T}_{7}$ (50\% Stevia $+50 \%$ Sugar) during storage.

\section{Taste}

The maximum score for taste of guava nectar and rts was recorded in treatment $\mathrm{T}_{3}(50 \%$ Equal $+50 \%$ Sugar) which is statistically at par with $\mathrm{T}_{7}$ (50\% Stevia $+50 \%$ Sugar) during storage. These findings were accordance with Kalra and Tandon (1991) and Choudhary et al., (2008) for guava nectar, Chakraborthy et al., (1991) for canned mango nectar, Pandey (2004) for guava beverages, Mall and Tandon (2007) for guava-aonla blended beverage, Kumar et al., (2008) for musambi RTS Beverage (Table 3).

\section{Overall acceptability}

The maximum score for overall acceptability of guava nectar and rts was found in treatment $\mathrm{T}_{3}(50 \%$ Equal $+50 \%$ Sugar) during storage. It may be due to non-enzymatic reactions like caramelization and millard. The score for overall acceptability of nectar was declined significantly during storage owing to oxidative reaction to deteriorate the scores of 
colour, flavour as well taste. These findings were accordance with Kalra and Tandon
(1991) and Choudhary et al., (2008) for guava nectar.

Table.1 Organoleptic evaluation of low calorie RTS beverages

\begin{tabular}{|l|l|l|l|l|}
\hline \multirow{2}{*}{ Treatment } & \multicolumn{4}{c|}{ Sensory evaluation } \\
\cline { 2 - 5 } & $\begin{array}{c}\text { colour and } \\
\text { appearance }\end{array}$ & aroma & taste & $\begin{array}{c}\text { overall } \\
\text { acceptability }\end{array}$ \\
\hline T0 : 100 per cent Sugar & 7.73 & 7.71 & 7.79 & 7.74 \\
\hline T1: 100 per cent Equal(Aspartame) & 7.71 & 7.63 & 7.22 & 7.49 \\
\hline T2:75 per cent Equal + 25 per cent Sugar & 7.69 & 7.68 & 7.76 & 7.71 \\
\hline T3: 50 per cent Equal + 50 per cent Sugar & 8.13 & 8.02 & 8.13 & 8.09 \\
\hline T4:25 per cent Equal + 75 per cent Sugar & 7.64 & 7.49 & 7.73 & 7.58 \\
\hline T5:100 per cent Stevia & 7.47 & 7.46 & 7.51 & 7.48 \\
\hline T6:75 per cent Stevia + 25 per cent Sugar & 7.37 & 7.32 & 7.53 & 7.40 \\
\hline T7:50 per cent Stevia + 50 per cent Sugar & 8.02 & 7.98 & 7.93 & 7.97 \\
\hline T8:25 per cent Stevia+ 75 per cent Sugar & 7.93 & 7.78 & 7.87 & 7.86 \\
\hline T9:100 per cent Splenda (Sucralose) & 7.16 & 7.08 & 6.47 & 6.87 \\
\hline T10:75 per cent Splenda + 25 per cent Sugar & 7.23 & 7.18 & 6.94 & 7.1 \\
\hline T11:50 per cent Splenda + 25 per cent Sugar & 7.34 & 7.31 & 7.06 & 7.19 \\
\hline T12:25 per cent Splenda+ 75 per cent Sugar & 7.18 & 7.29 & 6.50 & 7.05 \\
\hline SEm \pm & 0.011 & 0.011 & 0.010 & 0.010 \\
\hline CD at 5\% & 0.03 & 0.03 & 0.030 & 0.03 \\
\hline CV & 0.27 & 0.26 & 0.24 & 0.24 \\
\hline
\end{tabular}

Table.2 Effect of low calorie sweeteners on organoleptic score of guava nectar during storage

\begin{tabular}{|l|c|c|c|c|}
\hline \multirow{2}{*}{ Treatment } & \multicolumn{4}{|c|}{ Storage periods (days) } \\
\cline { 2 - 5 } & $\begin{array}{c}\text { Colour and } \\
\text { appearances }\end{array}$ & Aroma & Taste & $\begin{array}{c}\text { Overall } \\
\text { acceptability }\end{array}$ \\
\hline $\mathbf{T}_{\mathbf{0}}$ & 7.43 & 7.24 & 7.23 & 7.3 \\
\hline $\mathbf{T}_{\mathbf{1}}$ & 7.32 & 7.16 & 6.83 & 7.03 \\
\hline $\mathbf{T}_{\mathbf{2}}$ & 7.23 & 7.20 & 6.98 & 7.17 \\
\hline $\mathbf{T}_{\mathbf{3}}$ & 7.73 & 7.41 & 7.49 & 7.54 \\
\hline $\mathbf{T}_{\mathbf{4}}$ & 7.16 & 6.98 & 7.08 & 7.08 \\
\hline $\mathbf{T}_{\mathbf{5}}$ & 7.14 & 6.91 & 6.92 & 6.82 \\
\hline $\mathbf{T}_{\mathbf{6}}$ & 7.12 & 6.83 & 7.02 & 6.96 \\
\hline $\mathbf{T}_{\mathbf{7}}$ & 7.63 & 7.37 & 7.33 & 7.43 \\
\hline $\mathbf{T}_{\mathbf{8}}$ & 7.60 & 7.28 & 7.28 & 7.39 \\
\hline $\mathbf{T}_{\mathbf{9}}$ & 6.63 & 6.58 & 6.12 & 6.42 \\
\hline $\mathbf{T}_{\mathbf{1 0}}$ & 6.78 & 6.62 & 6.47 & 6.68 \\
\hline $\mathbf{T}_{\mathbf{1 1}}$ & 6.85 & 6.71 & 6.51 & 6.72 \\
\hline $\mathbf{T}_{\mathbf{1 2}}$ & 6.74 & 6.67 & 6.43 & 6.64 \\
\hline SEm $\mathbf{1}$ & 0.009 & 0.009 & 0.010 & 0.010 \\
\hline CD at 5 \% & 0.02 & 0.027 & 0.03 & 0.03 \\
\hline
\end{tabular}


Table.3

\begin{tabular}{|c|c|c|c|c|c|c|c|c|}
\hline \multirow[t]{3}{*}{ Treatment } & \multicolumn{8}{|c|}{ Storage periods (days) } \\
\hline & \multicolumn{4}{|c|}{ Nectar } & \multicolumn{4}{|c|}{ RTS } \\
\hline & $\mathbf{0}$ & 30 & 60 & 90 & $\mathbf{0}$ & 30 & 60 & 90 \\
\hline T0 : 100 per cent Sugar & 118 & 129 & 84 & 60 & 96 & 110 & 55 & 44 \\
\hline T1 : 100 per cent Equal(Aspartame) & 120 & 132 & 86 & 61 & 100 & 113 & 56 & 48 \\
\hline $\mathrm{T} 2: 75$ per cent Equal +25 per cent Sugar & 124 & 142 & 93 & 73 & 105 & 118 & 59 & 51 \\
\hline T3: 50 per cent Equal +50 per cent Sugar & 44 & 52 & 38 & 28 & 80 & 95 & 48 & 32 \\
\hline T4:25 per cent Equal +75 per cent Sugar & 126 & 148 & 95 & 85 & 110 & 128 & 64 & 48 \\
\hline T5:100 per cent Stevia & 132 & 149 & 97 & 87 & 118 & 137 & 68 & 52 \\
\hline T6:75 per cent Stevia +25 per cent Sugar & 141 & 152 & 99 & 89 & 120 & 145 & 73 & 56 \\
\hline T7:50 per cent Stevia +50 per cent Sugar & 110 & 120 & 79 & 63 & 85 & 99 & 49 & 37 \\
\hline T8:25 per cent Stevia+ 75 per cent Sugar & 116 & 126 & 81 & 67 & 89 & 103 & 52 & 41 \\
\hline T9:100 per cent Splenda (Sucralose) & 145 & 155 & 97 & 85 & 122 & 147 & 74 & 62 \\
\hline T10:75 per cent Splenda +25 per cent Sugar & 149 & 159 & 112 & 95 & 134 & 152 & 76 & 68 \\
\hline T11:50 per cent Splenda +25 per cent Sugar & 152 & 162 & 128 & 97 & 151 & 167 & 84 & 72 \\
\hline T12:25 per cent Splenda+ 75 per cent Sugar & 146 & 151 & 124 & 93 & 143 & 157 & 78 & 70 \\
\hline $\mathrm{SEm} \pm$ & 1.40 & 1.45 & 1.52 & 1.53 & 1.33 & 1.33 & 1.36 & 1.44 \\
\hline $\mathrm{CD}$ at $5 \%$ & 4.06 & 4.21 & 4.41 & 4.43 & 3.854 & 3.84 & 3.95 & 4.17 \\
\hline
\end{tabular}




\section{Microbial analysis}

Microbiological studies like total plate count of bacteria, yeast and mould count, coliform and E. coli count were carried out at 1 st and 3rd month for the processed products stored at two different storage periods to evaluate the safety and keeping quality of the products.

\section{Total plate count (TPC)}

Total plate count was carried out till 10-9 dilution level. There was a significant difference in TPC among the products and storage conditions at different storage periods. Squash contained significantly higher number of bacteria (365). The TPC was significantly higher in products stored at room temperature than at cold storage. There were significant differences in TPC of products among the storage periods. The TPC increased with the increase in storage periods in all the products. The interaction effects of products and storage conditions were significant for all the dilutions. At room temperature TPC in nectar was on par, which different significantly with squash with high number of TPC (510). In cold storage also similar trend appeared and the products differed significantly among themselves with highest in squash (220). At cold storage nectar was on par.

\section{Yeast and mould count}

Yeast and mould count was carried out till 103 dilution. There was a significant difference in yeast and mould count among the products and storage conditions at different storage periods. Squash contained significantly higher number of yeast and moulds (480). The yeast and mould count was significantly higher in products stored at room temperature than cold storage. There were significant differences in yeast and mould count of products among the storage periods. The yeast and mould count increased with increase in storage periods.
The interaction effects of products and storage conditions were significant. At room temperature nectar was on par. All the products stored at room temperature differed significantly with squash with high number of count. In cold storage also similar trend appeared and the products differed significantly among themselves with highest in squash (360). There was a significant increase in yeast and mould count in all the products at room temperature compared to cold storage.

There were significantly differences for the interaction effects between products and storage periods. There was significant increase in the growth of yeast and mould with the storage period in all the products. The interaction effects between storage periods and storage conditions were significant. Both the products stored at room temperature and cold storage showed significant increase in yeast and mould count with increase in storage periods.

All the processed guava products were initially evaluated organoleptically for their appearance, color, flavor, taste and overall acceptability. A maximum score of 5 was taken as standard for considering the quality of the products. All the products ranked excellent in all the quality characteristics. There was a considerable decrease in sensory mean score for taste, flavor and overall acceptability during storage. The sensory mean score for each attributes was highest on the day of preparation which decreased with passage of time. The overall acceptability of the products decreased as the storage period increased. Organoleptic evaluation of processed products remained more acceptable for products stored at low temperature compared to that at room temperature. Microbial analysis of the store pulp after a storage period of 3 months showed very less or negligible total bacterial count and fungal 
count.

\section{References}

Chakraborthy, S., Bisht, H.C., Agarwal, M.D., Verma, L.N. and Shukla, I.C. 1991. Studies on varietal screening of mangoes of Uttar Pradesh for their suitability for production of canned nectar, Juice and pulp. Indian Fd. Pack. 55: 49-57.

Choudhary, M. L. 2004. Evaluation of guava (Psidium guajava L.) varieties and of recipe for nectar preparation. M. Sc. (Ag.) Thesis. I.G.K.V., Raipur (C.G)

Jagtiani, J., Chan, H. T. and Sakai, W. S. (1998). Guava. In Tropical fruit processing. New York: Academic Press.

Kalra, S.K., Tandon, D.K. and Singh, B.P. 1991, "Evaluation of mango-papaya blended beverage", Indian Fd. Pack., 45: 33-36.
Kumar, K., Sharma A, and Barmanray, A. 2008 Storage stability of musambi (Citrus sinensis) RTS Beverages in different storage conditions. Beverages and food Beverages World. 35: 47-48

Leite, K.M.S.C., Tadiotti, A.C., Baldochi, D. and Oliveira, O.M.M.F. (2006). Partial purification, heat stability and kinetic characterization of the pectin methylesterase from Brazilian guava Plauma cultivars. Food Chemistry. 94, 565-572

Mall, P. and Tondon, D.K. 2007. Develpoment of guava-aonla blended beverage. Acta Horticulturae, 735: 555560.

Somogyi, L. P., Barrett, D. M. and Hui, Y. H. 1996. Major processed product. Technomic Publishing Pulp (blanched) Guava RTS nectar different guava Products.

\section{How to cite this article:}

Nisha Chandel, Vivek Kumar Kurrey, Pramila Seth, Apurwa Kesharwani and Atul Praveen Panna. 2017. Evaluation of Organolepictic Properties and Microbial Studies of Guava Nectar and RTS. Int.J.Curr.Microbiol.App.Sci. 6(12): 2207-2213. doi: https://doi.org/10.20546/ijcmas.2017.612.253 